\title{
Comparative study of environmental pollutants bisphenol $A$ and bisphenol $S$ on sexual differentiation of anteroventral periventricular nucleus and spermatogenesis
}

\author{
Naham John ${ }^{1}$, Humaira Rehman ${ }^{1}$, Suhail Razak ${ }^{1,2^{*}}$ (D) Mehwish David ${ }^{1}$, Waheed Ullah¹, Tayyaba Afsar²,
} Ali Almajwal', |ftikhar Alam² and Sarwat Jahan'

\begin{abstract}
Background: Bisphenol A is well known endocrine-disrupting chemical while Bisphenol S was considered a safe alternative. The present study aims to examine the comparative effects of xenobiotic bisphenol-A (BPA) and its substitute bisphenol-S (BPS) on spermatogenesis and development of sexually dimorphic nucleus population of dopaminergic neurons in the anteroventral periventricular nucleus (AVPV) of the hypothalamus in male pups.

Methods: Sprague Dawley rat's pups were administered subcutaneously at the neonatal stage from postnatal day PND1 to PND 27. Thirty animals were divided into six experimental groups ( 6 animals/group). The first group served as control and was provided with normal olive oil. The four groups were treated with $2 \mu \mathrm{g} / \mathrm{kg}$ and $200 \mu \mathrm{g} / \mathrm{kg}$ of BPA and BPS, respectively. The sixth group was given with $50 \mu \mathrm{g} / \mathrm{kg}$ of estradiol dissolved in olive oil as a standard to find the development of dopaminergic tyrosine hydroxylase neurons in AVPV regions. Histological analysis for testicular tissues and immunohistochemistry for brain tissues was performed.

Results: The results revealed adverse histopathological changes in testis after administration of different doses of BPA and BPS. These degenerative changes were marked by highly significant $(p<0.001)$ decrease in tubular and luminal diameters of seminiferous tubule and epithelial height among bisphenols treated groups as compared to control. Furthermore, significantly increased $(p<0.001)$ TH-ir cell bodies in the AVPV region of the brain with $200 \mu \mathrm{g} / \mathrm{kg}$ dose of BPA and BPS was evident.
\end{abstract}

Conclusion: It is concluded that exposure of BPA and BPS during a critical developmental period can structural impairments in testes and affects sexual differentiation of a dimorphic dopaminergic population of AVPV region of hypothalamus in the male brain.

Keywords: Endocrine disruptor, Bisphenol A, Bisphenol S, Immunohistochemistry, AVPV

\footnotetext{
* Correspondence: ruhail12345@yahoo.com; smarazi@ksu.edu.sa

${ }^{1}$ Reproductive Physiology Lab, Department of Animal Sciences, Quaid- i-

Azam University Islamabad, Islamabad 45320, Pakistan

${ }^{2}$ Department of Community Health Sciences, College of Applied Medical

Sciences, King Saud University, Riyadh, Kingdom of Saudi Arabia
}

(c) The Author(s). 2019 Open Access This article is distributed under the terms of the Creative Commons Attribution 4.0 International License (http://creativecommons.org/licenses/by/4.0/), which permits unrestricted use, distribution, and reproduction in any medium, provided you give appropriate credit to the original author(s) and the source, provide a link to the Creative Commons license, and indicate if changes were made. The Creative Commons Public Domain Dedication waiver (http://creativecommons.org/publicdomain/zero/1.0/) applies to the data made available in this article, unless otherwise stated. 


\section{Background}

Bisphenol A (BPA) is employed in industry, particularly in polycarbonate plastics industrial processes and foodstuff containers. The resiliency of BPA plastics has led to their use in medical equipment's such as heart-lung machines, incubators, hemodialyzers, and dental sealants and fillers; also, their light weight and optical clarity have made them especially useful for eyeglasses. Phthalates help make plastic, like pacifiers, flexible. Due to his widespread applications, the use of BPA has gathered cumulative consideration over the last decade, particularly in terms of human safety. It is believed that both BPA and phthalates can leach from the plastic into food, liquid, and directly into the mouths of children while sucking on pacifiers or teethers. It has been estimated that levels of conjugates of BPA in urine are above safety thresholds in $90 \%$ of individuals tested in several population studies [1]. Fetal exposure to high doses of dibutyl phthalate was shown to cause a testicular dysgenesis syndrome (TDS)-like phenotype in the rats [2]. TDS is a male reproduction-related condition characterized by the presence of symptoms and disorders such as hypospadias, cryptorchidism, poor semen quality, and testicular cancer. TDS is a result of disruption of embryonal programming and gonadal development during fetal life [2] Various reports established that BPA acts as an endocrine disrupting chemical and its exposure can affect the reproductive system of a male by disturbing spermatogenesis and fertility, furthermore, its exposure during development causes organizational effects on brain [3-10]. BPA has increased excess to estrogen sensitive tissues in brain [16]. At the hypothalamic or pituitary level, BPA may inhibit the estrogen binding to its receptors. Thus, circulating estrogen reduces its negative feedback actions on luteinizing hormone (LH) and follicle stimulating hormone (FSH) release, resulting in high levels of circulating $\mathrm{LH}$ and FSH. Thus, it is suggested that BPA's actions are greater during development[13-15].

Bisphenol S (4, 4'-dihydroxydiphenyl sulphone) abbreviated as BPS, is a man made, industrial chemical and another member of bisphenol family. BPS has increased stability and resistance against sunlight and high temperatures. Like BPA, BPS is an endocrine disrupting molecule and its increasing use is alarming for human health [11]. In zebrafish, BPS exposure has shown to induce a reduction in gonadal weight, alteration in hormonal and disruption in the normal process of reproduction (i.e. decreases egg production and hatchability, increases embryo malformations, increase in time to hatch) [17]. BPS exposure also decreases body length, increases male and female sex ratio and causes reproductive disruption, disturbs the balance of sex steroid hormones in adult zebrafish [18]. Several studies show androgenic and anti-androgenic activities of BPS [19]. Similar to BPA, BPS can induce alterations in an embryonic, nervous and endocrine system [17, 20, 21]. Exposure of BPA and BPS to zebrafish embryo causes 180 and $240 \%$ increase in hypothalamic neurogenesis [21]. During early developmental stages, BPA exposure has been suspected to affect testicular development and spermatogenesis [22, 23].

In mammals, ovaries are generally quiescent in developing females, so reproductive tract and brain development occurs in the absence of estrogen. Whereas in developing male, elevated estrogen levels locally synthesized by aromatization of testosterone (testicular) are present. The sexual differentiation of estrogen exposure and hormonal synthesis results into distinct development of neuroanatomical circuits, neuroendocrine functions, and reproductive behaviors in both male and females [24]. The anteroventral periventricular nucleus (AVPV) is a small cluster of neurons along the wall of the third ventricle just caudal to the vascular organ of lamina terminalis (OVLT). AVPV receives sexually dimorphic innervation by dopaminergic afferents that regulate gonatropin-releasing hormone and sexual reproduction $[25,26]$. AVPV is three times more sexually dimorphic in females, being larger in volume and containing more cells in females than male. This suggests that this brain region is very important in controlling the estrous cyclicity in females. In female AVPV, for dopamine synthesis, the rate limiting enzyme tyrosine hydroxylase $(\mathrm{TH})$ expressing neurons are more abundantly and topographically distributed and are distinct from males [26, 27]. The perinatal administration of testosterone or estrogen can defeminize the neuron count and distribution in female AVPV [28]. One of the function of TH cells of AVPV is to regulate the secretion of gonadotropin releasing hormone $(\mathrm{GnRH})$ neurons in the medial preoptic area (POA) [29]. Total numbers of THcells are more in female's AVPV than males, hence sexually dimorphic GnRH secretions. Estradiol administration have no effect on $\mathrm{TH}$ cell numbers in males and it is suggested that BPA have antiestrogen action on this neural cell population [24].

If it is speculated that BPA acts as estrogen or an antiestrogen in the AVPV region, then it can be hypothesized that more or less sexually dimorphic areas could be affected by exposure to BPA or BPS. Considering our chosen endocrine active compounds to be estrogenic, masculinization of female AVPV should be evident via a reduction in $\mathrm{TH}$-expressing neurons number. In contrast, anti-estrogenic bisphenols through increment in TH-expressing neurons count should de-masculinized the male AVPV.

This study was designed to determine the low dose effect of BPA and BPS on sexual differentiation of the AVPV region of the male brain at the neonatal stage and to find out the possible role of endocrine disrupting 
chemicals on the reproductive system of male rats at initial stages of life. These finding will further provide the evidence of negative effects of BPA and its analogue BPS on the reproductive system of male rats.

\section{Methods \\ Animals}

At the start, five wooden breeding cages were separated and five adult female Sprague Dawley rats were kept in each breeding cage with two adult male Sprague Dawley rats. Ten days later, adult male rats were separated from females. Laboratory pelleted food and water was available to animals ad libitum. Pregnant females were reared singly till the birth of pups on day 22 (gestational dayGD-22). The day of birth of the pups was called as postnatal day 1 (PND1. Total numbers of pups were counted and separated from female pups by measuring the anogenital distance (AGD) under a stereomicroscope. For each experimental group, six male pups were separated from each litter. Animals were handled and sacrificed according to the guidelines provided by the Ethical Committee of Animal Sciences department, Faculty of Biological Sciences, Quaid-i-Azam university, Islamabad.

\section{Experimental plan}

Newborn pups (PND1) animals were distributed into six groups ( $n=6 /$ group). The first group served as control and received subcutaneous injection of olive oil $(50 \mu \mathrm{l})$. The second and third group rats were treated with BPA $(2 \mu \mathrm{g} / \mathrm{kg}$ and $200 \mu \mathrm{g} / \mathrm{kg})$ respectively. Fourth and fifth group male pups were injected with BPS $(2 \mu \mathrm{g} / \mathrm{kg}$ and $200 \mu \mathrm{g} / \mathrm{kg}$ ) respectively. The sixth group was given with $50 \mu \mathrm{g} / \mathrm{kg}$ of estradiol dissolve in olive oil as a standard to a find development of dopaminergic tyrosine hydroxylase neurons in AVPV regions. All treatments were dissolved in olive oil and were given from PND 1 to PND 27 with reference to prior studies [30-32]. Estradiol treated group was only used to serve as a standard to find a development of dopaminergic tyrosine hydroxylase neurons in AVPV of rodents' hypothalamus. All dosages were adjusted daily according to body weight. We selected a higher dose of $200 \mu \mathrm{g} /$ $\mathrm{kg}$ because it is higher suspected human exposure dose and a low dose of $2 \mu \mathrm{g} / \mathrm{kg}$ approaches to human exposure level [24, 33].

On PND 27, animals were weighed (using Sarotoreious Digital Balance) and sacrificed by decapitation. The brain tissues were used only for immunohistochemistry. Testicular tissues were dissected out for tissue histology and were washed in saline and weighed. Other tissues (brain, kidney, liver, and intestine) were also dissected out and weighed also.

\section{Histological analysis}

Histological analysis was done exactly by using a method given by Ullah et al. [34]. Firstly, testis was kept in sera (composed of ethyl alcohol, formaldehyde, and glacial acetic acid in a ratio of 6:3:1), and then placed in 10\% formalin for 24 to $48 \mathrm{~h}$. Following fixation, tissues were dehydrated with ascending grades of ethanol, cleared with xylene and embedded in paraffin wax. Microtomy was then carried out and seven $\mu \mathrm{m}$ thick sections of testis were cut (Thermo, Shandon finesse 325, UK). Testis sections were then fixed on albumenized glass slides, placed in an incubator overnight for completion of deparaffinization and on next day, were stained with hematoxylin and eosin and then, observed under the light microscope (Nikon, 187,842, Japan). Leica LB microscope (Germany) equipped with canon digital camera was used for microphotography. For histolomorphometric studies, Image J software was used for the measurement of testis parameters (National Institutes of Health, Bethesda, MD, USA).

\section{Brain tissue fixation and processing}

The entire hypothalamic blocks of the brain were placed in $4 \%$ paraformaldehyde overnight. Next day, these samples were dehydrated and cleared through different grades of ethanol and xylene follow embedding in paraffin wax. The tissue was then deparaffinized with xylene and rehydrated in graded ethanol before being washed with twice-distilled water. Later, hypothalamic blocks were cut into consecutive sections of $7-10 \mu \mathrm{m}$ thickness on a cryostat (Bright OTF 5000, A-M Systems, Sequim, Washington, USA; temperature $-25^{\circ} \mathrm{C}$ ) and preserved in an antifreeze cryoprotectant solution (1\% polyvinylepyrrolidone, $30 \%$ ethylene glycol and 30\% sucrose in PBS) at $20^{\circ} \mathrm{C}$ until used for immunocytochemistry.

\section{Immunocytochemistry}

Standard double immunocytochemistry protocol was followed for the processing of hypothalamic sections. Total numbers of $\mathrm{TH}$ cell bodies were immunolocalized in the mediobasal hypothalamic region using a cocktail of primary antibodies directed against $\mathrm{TH}$. For $\mathrm{TH}$ expression monoclonal antibody $\mathrm{TOH}$ A1.1 raised in mouse against human TH (Catalogue no. ab-150,659; Abcam Biotechnology, Inc., Cambridge, United Kingdom) was used and Alexa Flour 488 labeled goat antimouse IgG (Catalogue no. ab150117; Abcam, Cambridge, UK) was used as a secondary antibody. From each animal, three slides of hypothalamus were obtained for TH labeled immunostaining. While, one section from each group was used as primary antibody omitted control. Hypothalamic sections were washed with phosphate buffered saline (PBS; PH7.3) (Omnipur PBS tablets, 
Calbiochem, EDM chemicals Inc., Gibbstown, New Jersey, USA) for $8 \times 15$ minutes at room temperature $\left(25^{\circ} \mathrm{C}\right)$, to remove the cryoprotectant afterwards sections were incubated in incubation solution containing $10 \%$ normal goat serum, $0.05 \%$ Triton-X 100 and $0.1 \%$ bovine serum albumin (BSA) in PBS for two hours on shaker at room temperature to block the non-specific binding of the antibodies. Sections were then washed with PBS for $3 \times 15$ minutes. Then sections were incubated at $4{ }^{\circ} \mathrm{C}$ for $48 \mathrm{~h}$ on a shaker in a cocktail of primary antibodies (anti-TH antibody at 1:20) diluted at PBS containing $10 \%$ normal goat serum, $0.03 \%$ Triton X- 100 and 0.5 BSA. Control sections were incubated in PBS with $10 \%$ normal goat serum in PBS containing $0.05 \%$ TritonX100 and $0.1 \%$ BSA. After incubation of $48 \mathrm{~h}$, sections were washed in PBS for $3 \times 15 \mathrm{~min}$ at room temperature. After washing, the sections were incubated in the cocktail of secondary antibodies Alexa Flour 488 labeled goat anti-mouse at 1:1000 diluted in PBS containing $0.05 \%$ Triton $\mathrm{X}-100$ and 0.1 BSA $10 \%$ normal goat serum for $2 \mathrm{~h}$ in dark, at room temperature on a shaker. Control sections were also incubated with secondary antibodies at this stage. After incubations, sections were again washed with PBS $3 \times 15 \mathrm{~min}$. Later, all sections were mounted on super frosted glass slides (Micro slides, Santa Cruz Biotechnologies, Dallas, Texas USA) and left overnight for drying at $4{ }^{\circ} \mathrm{C}$ in dark. Then coverslip was placed on slides using laboratory-prepared gelvatol as a mounting medium. Gelvatol was prepared by adding $10.5 \mathrm{~g}$ polyvinyl alcohol and few crystals of sodium azide in $12 \mathrm{ml}$ glycerol. Then $21 \mathrm{ml}$ distilled water and $53 \mathrm{ml}$ Tris $(\mathrm{Ph}$ 8.5) were added. The mixture was stirred on low heat for six hours until reagents were properly dissolved. The mixture was placed overnight in a refrigerator and centrifuged at $5000 \mathrm{~g}$ for 15 minutes. Slides were stored at $4{ }^{\circ} \mathrm{C}$ after drying until further analysis. Slides were viewed using fluorescent microscope (Bx51, Olympus, Tokyo, Japan) to localize, Tyrosine hydroxylase immuno-reactive neurons in the AVPV region of the brain. Sections were examined at 10X, 20X and 40X magnifications.

\section{Statistical analysis}

For histological data analysis of testes and the number of single TH-immunoreactivity cells, GraphPad prism 5 software (GraphPad Software, Inc., San Diego, CA, USA) was used. One way analysis of variance (ANOVA) was used for statistical analysis of studied parameters. Later, Dunnet's multiple comparison tests were practiced to relate the controls results with treated ones. All the data is shown as mean \pm SEM. Significance value was set at $p<0.05$.

\section{Results}

Effect of subcutaneous exposure of bisphenol A bisphenol $\mathrm{S}$ on body weight $(\mathrm{g})$ in male rats, during the neonatal period

Mean \pm SEM body weight of all experimental groups in male rats are shown in Table 1. As compared to control group, significant $(\mathrm{p}<0.05)$ change was detected in body weight recorded on PND 8, among low and high concentrations of BPA groups. On PND 16, very remarkable increment $(p<0.001)$ was noticed in body weight among BPA $2 \mu \mathrm{g} / \mathrm{kg}$ and BPS $2 \mu \mathrm{g} / \mathrm{kg}$ treated groups comparison with control. Animals treated with BPS $200 \mu \mathrm{g} / \mathrm{kg}$ showed significance change $(p<0.05)$ than control group. BPA $(2 \mu \mathrm{g} / \mathrm{kg}$ dose $)$ induced significant $(p<0.01)$ increase in body weight on PND 24 compared to the control group.

\section{Effect of subcutaneous exposure of BPA and BPS on weight of testis $(\mathrm{g})$, prostate $(\mathrm{g})$, seminal vesicle $(\mathrm{g})$, liver (g), heart (g) and kidney (g)}

Table 2 indicated the effect of various treatments of BPA and BPS on organ weights of rats.

Testicular weight seen to be increased $(\mathrm{p}<0.05)$ in BPA $2 \mu \mathrm{g} / \mathrm{kg}$, BPS $2 \mu \mathrm{g} / \mathrm{kg}$ and BPS $200 \mu \mathrm{g} / \mathrm{kg}$ treated groups than the control. No significant differences were noticed in prostrate, seminal vesicle, liver and kidney weights when all experimental groups were compared to control. Heart weight of BPA and BPS $2 \mu \mathrm{g} / \mathrm{kg}$ and $2 \mu \mathrm{g} /$ $\mathrm{kg}$ treated animals show significance change $(\mathrm{p}<0.01)$ as compared to control.

\section{Tissues histology}

The histological studies of the testis showed closely arranged seminiferous tubules and normal spermatogenesis in the control group. A photomicrograph of a section of the testis of 27 days old albino rat of the BPA $2 \mu \mathrm{g} / \mathrm{kg}$ group showing a prominent increase in the interstitial spaces between seminiferous tubules appeared irregular and smaller in size as compared to control group. A decrease was observed in the epithelial diameter so it is evident that there will be a reduction in the number of spermatogonia and primary spermatocytes near the lumen of the tubule. Some germ cells appeared shattered and separated with the appearance of empty spaces; some appeared desquamated toward the lumen with the disappearance of the early spermatids. Lumen diameter in BPA $2 \mu \mathrm{g} / \mathrm{kg}$ treated group was increased as compared to the control group. BPA $200 \mu \mathrm{g} /$ $\mathrm{kg}$ treated rat testis showing a normal testis structure with a slight decrease in tubular diameter as compared to BPA $2 \mu \mathrm{g} / \mathrm{kg}$. There was an increase in the interstitial spaces between the tubules with a slight appearance of destructed Leydig cells. BPA $200 \mu \mathrm{g} / \mathrm{kg}$ treated rats showed less loss of stratification and disorganization of 
Table 1 Comparative effects of different concentrations $(2 \mu \mathrm{g} / \mathrm{kg}, 200 \mu \mathrm{g} / \mathrm{kg})$ of Bisphenol A and Bisphenol S on body weight (g) recorded on 8th, 16th, 24th and 28th day of development

\begin{tabular}{lllll}
\hline Groups & Day 8 & Day 16 & Day 24 & Day 28 \\
\hline Control & $9.71 \pm 0.52$ & $12.4 \pm 0.87$ & $20.5 \pm 0.92$ & $43.7 \pm 6.54$ \\
BPA $(2 \mu \mathrm{g} / \mathrm{kg})$ & $13.6 \pm 0.65$ & $21.9 \pm 0.32 \mathrm{a}^{* *}$ & $35.3 \pm 0.60 \mathrm{a}^{* *}$ & $40.1 \pm 1.66$ \\
BPA $(200 \mu \mathrm{g} / \mathrm{kg})$ & $13.0 \pm 0.30$ & $12.8 \pm 0.87$ & $19.4 \pm 1.88$ & $37.6 \pm 3.38$ \\
BPS $(2 \mu \mathrm{g} / \mathrm{kg})$ & $11.5 \pm 0.28$ & $19.9 \pm 1.50 \mathrm{a}^{* *} \mathrm{C}^{* * *}$ & $28.9 \pm 2.79$ & $40.4 \pm 0.32$ \\
BPS $(200 \mu \mathrm{g} / \mathrm{kg})$ & $13.9 \pm 0.38$ & $17.2 \pm 0.41 \mathrm{a}^{*}$ & $31.6 \pm 2.12 \mathrm{a}^{* \mathrm{C}^{* * *}}$ & $38.5 \pm 2.05$ \\
\hline
\end{tabular}

Values are expressed as mean SEM ${ }^{*} p<0.05,{ }^{* *} p<0.01, p^{* * *}<0.001$

$\mathrm{a}=$ Values vs control, b = Values vs Bisphenol A $2 \mu \mathrm{g} / \mathrm{kg}, \mathrm{c}=$ Values vs Bisphenol A $200 \mu \mathrm{g} / \mathrm{kg}, \mathrm{d}=$ Values vs Bisphenol S $2 \mu \mathrm{g} / \mathrm{kg}$

the lining epithelium of the seminiferous tubules show more closely resembled to control group. Epithelial layer contained spermatogonia, primary spermatocytes, and early spermatids. Some interfollicular spaces of the tubules showed destructed interstitial tissue and most sections of testis treated with BPA $200 \mu \mathrm{g} / \mathrm{kg}$ shows a reduction in lumen diameter show slight variation as compare to control group. Histomorphology of the testicular section from BPS $2 \mu \mathrm{g} / \mathrm{kg}$ showed a major difference in the appearance of seminiferous tubules compared to control group. Lumen diameter is somehow appeared similar to the control group.

\section{Seminiferous tubule diameter}

Significantly increased $(p<0.001)$ diameter was observed when BPA $2 \mu \mathrm{g} / \mathrm{kg}$ and BPS $200 \mu \mathrm{g} / \mathrm{kg}$ treated groups compare with a control group. No significant difference was found when compared BPS $2 \mu \mathrm{g} / \mathrm{kg}$ treated group with BPA $200 \mu \mathrm{g} / \mathrm{kg}$ treated groups as compared to control. (Table 3, Fig. 1).

\section{Tubular lumen diameter}

Mean tubular lumen diameter in BPA treated animals was decreased significantly $(p<0.001)$ as compare to control animals. Statistical difference in the mean of the lumen diameter was decreased significantly $(p<0.01)$ when compare BPA $200 \mu \mathrm{g} / \mathrm{kg}$ treated group with a control group. A highly significant decrease $(p<0.001)$ in tubular lumen diameter was observed in BPS $2 \mu \mathrm{g} / \mathrm{kg}$ and BPS $200 \mu \mathrm{g} / \mathrm{kg}$ treated groups respectively when compared to control group (Table 3, Fig. 1).

\section{Epithelial height}

Mean epithelial thickness was decreased significantly $(p<0.001)$ in BPA $2 \mu \mathrm{g} / \mathrm{kg}$ treated group as compare to control group. Highly significant $(p<0.001)$ reduction was seen in BPA $200 \mu \mathrm{g} / \mathrm{kg}$ treated group as compare to control group. There was highly significant $(p<0.001)$ decrease in mean was observed between BPS $200 \mu \mathrm{g} / \mathrm{kg}$ treated group and BPS $2 \mu \mathrm{g} / \mathrm{kg}$ treated group as compare to control group (Table 3, Fig. 1).

\section{Tunica Albugenia height}

There was no significant change was noticed in Tunica Albuginea height among all treated groups except BPA $2 \mu \mathrm{g} / \mathrm{kg}$ showed significant decrease $(p<0.005)$ with their comparison to that of the control group (Table 3 , Fig. 1).

\section{TH immunoreactive cells}

TH expression is sexually dimorphic in the AVPV region of brain. No significant alterations were observed in THir cell number between control, estradiol and a low dose of BPA $2 \mu \mathrm{g} / \mathrm{kg}$ treated groups. Extremely prominent $(p<0.001)$ rise was seen in the TH-ir cell bodies between BPA $200 \mu \mathrm{g} / \mathrm{kg}$ treated group and control group. Treatment with a low dose of BPS $200 \mu \mathrm{g} / \mathrm{kg}$ and a high dose of BPS $2 \mu \mathrm{g} / \mathrm{kg}$ were significantly $(p<0.001)$ different from control group (Table 4, Fig. 2).

\section{Discussion}

Over the last decade, it has become well known that BPA, a ubiquitous environmental endocrine disruptor

Table 2 Comparative effects of different concentrations $(2 \mu \mathrm{g} / \mathrm{kg}, 200 \mu \mathrm{g} / \mathrm{kg})$ of Bisphenol A and Bisphenol S on body organs weight

\begin{tabular}{lllllll}
\hline Groups & Testes paired weight(g) & Prostate $(\mathrm{g})$ & Seminal Vesicle $(\mathrm{g})$ & Liver $(\mathrm{g})$ & Heart $(\mathrm{g})$ & Kidney $(\mathrm{g})$ \\
\hline Control & $0.74 \pm 0.19$ & $0.04 \pm 0.01$ & $0.34 \pm 0.19$ & $1.90 \pm 0.20$ & $0.58 \pm 0.22$ & $0.59 \pm 0.21$ \\
BPA $2 \mu \mathrm{g} / \mathrm{kg}$ & $0.24 \pm 0.01 \mathrm{a}^{*}$ & $0.06 \pm 0.01$ & $0.03 \pm 0.01$ & $1.90 \pm 0.17$ & $0.20 \pm 0.01^{* *}$ & $0.45 \pm 0.01$ \\
BPA $200 \mu \mathrm{gg} / \mathrm{kg}$ & $0.39 \pm 0.17$ & $0.05 \pm 0.01$ & $0.01 \pm 0.0$ & $1.92 \pm 0.08$ & $0.23 \pm 0.02^{* *}$ & $0.49 \pm 0.02$ \\
BPS $2 \mu \mathrm{g} / \mathrm{kg}$ & $0.25 \pm 0.01$ & $0.02 \pm 0.01 \mathrm{~b}^{* *}$ & $0.09 \pm 0.07$ & $1.63 \pm 0.13$ & $0.23 \pm 0.01^{* *}$ & $0.55 \pm 0.00$ \\
BPS $200 \mu \mathrm{g} / \mathrm{kg}$ & $0.24 \pm 0.03$ & $0.02 \pm 0.01 b^{* *}$ & $0.02 \pm 0.01$ & $1.43 \pm 0.15$ & $0.23 \pm 0.02^{* *}$ & $0.47 \pm 0.02$ \\
\hline
\end{tabular}

Values are expressed as mean SEM

${ }^{*} p<0.05, * * 0<0.01, \mathrm{p}^{* * *}<0.001$

$\mathrm{a}=$ Values vs control, $\mathrm{b}=$ Values vs Bisphenol A $2 \mu \mathrm{g} / \mathrm{kg}, \mathrm{c}=$ Values vs Bisphenol A $200 \mu \mathrm{g} / \mathrm{kg}, \mathrm{d}=$ Values vs Bisphenol S $2 \mu \mathrm{g} / \mathrm{kg}$ 
Table 3 Mean \pm SEM of seminiferous tubule diameter, tubular lumen diameter, seminiferous tubule epithelial height, tunica albuginea height of testis in control and treated groups after 28 days of treatment

\begin{tabular}{lllll}
\hline Groups & $\begin{array}{l}\text { Seminiferous } \\
\text { Tubule Diameter }\end{array}$ & $\begin{array}{l}\text { Lumen } \\
\text { Diameter }\end{array}$ & Epithelial Height & $\begin{array}{l}\text { Tunica Albuginea } \\
\text { Height }\end{array}$ \\
\hline Control & $106.46 \pm 2.94$ & $84.19 \pm 3.46$ & $35.59 \pm 0.63$ & $19.79 \pm 1.14$ \\
BPA $2 \mu \mathrm{gg} / \mathrm{kg}$ & $126.03 \pm 4.19^{\mathrm{a***}}$ & $61.72 \pm 3.09^{\mathrm{a} * * *}$ & $23.00 \pm 0.48^{\mathrm{a***}}$ & $16.34 \pm 0.54$ \\
BPA $200 \mu \mathrm{gg} / \mathrm{kg}$ & $133.98 \pm 3.23^{\mathrm{a} * * *}$ & $71.22 \pm 2.60^{\mathrm{a} * *}$ & $25.16 \pm 0.48^{\mathrm{ab} * * *}$ & $17.66 \pm 0.90$ \\
BPS $2 \mu \mathrm{g} / \mathrm{kg}$ & $106.60 \pm 2.46^{\mathrm{bc***}}$ & $62.90 \pm 1.77^{\mathrm{a} * * *}$ & $32.39 \pm 0.54^{\mathrm{abc***}}$ & $18.61 \pm 0.63$ \\
BPS $200 \mu \mathrm{g} / \mathrm{kg}$ & $114.29 \pm 2.45^{\text {c***}}$ & $64.86 \pm 2.20^{\mathrm{a} * * *}$ & $26.55 \pm 0.57^{\mathrm{abd***}}$ & $18.19 \pm 0.67$ \\
\hline
\end{tabular}

Values are expressed as mean SEM

${ }^{*} p<0.05,{ }^{* *} p<0.01, p^{* * *}<0.001$

$\mathrm{a}=$ Values vs control, b = Values vs Bisphenol A $2 \mu \mathrm{g} / \mathrm{kg}, \mathrm{c}=$ Values vs Bisphenol A $200 \mu \mathrm{g} / \mathrm{kg}, \mathrm{d}=$ Values vs Bisphenol S $2 \mu \mathrm{g} / \mathrm{kg}$

administration causes reproductive toxicity and gonadal damage [35-39]. Similarly, BPS is another strong estrogenic and anti-androgenic compound, which has been banned now in different countries due to its toxic effects on the physiology of the reproductive system $[19,40,41]$.

The present study shows irreversible organizational effects in testis of prepubertal male rats exposed to BPA and BPS different concentrations $(2 \mu \mathrm{g} / \mathrm{kg}$ and $200 \mu \mathrm{g} /$ $\mathrm{kg}$ ) during the neonatal stage [42]. We observe no significant change in final body weight in all treatment groups. These results are similar to a study where animals were treated with $50 \mu \mathrm{l}$ genistein and $5 \mu \mathrm{g} / \mathrm{kg}$ BPA (Gen/BPA 0.005) and no significant change in body weight were observed [43]. Alike results were experienced in postnatal male mice as compared to control mice when administered with BPA at early embryonic stage [36]. Ullah et al. (2016) also noticed no alteration in body weight of adult male rats after sub-chronic oral administration of BPS [34]. However, in the current study significant increase in body weights was recorded at PND 16 and PND 24 in BPA $(2 \mu \mathrm{g} / \mathrm{kg})$ and BPS $(2 \mu \mathrm{g} /$ $\mathrm{kg}$ and $200 \mu \mathrm{g} / \mathrm{kg}$ ) treated groups. Our results are in accordance with the former study by Rubin et al. (2001) where female rat dams, when exposed to BPA from day 6 of pregnancy until lactation, resulted in increased body weight relative to control group in offspring [45]. Previously, Sakaue et al. reported that exposure of BPA $(2 \mu \mathrm{g} /$ $\mathrm{kg}$ to $200 \mu \mathrm{g} / \mathrm{kg}$ ) to adult male rats resulted in decreased testicular weight and impaired spermatogenesis [44].

It is known that administration of exogenous estrogen results in reduced adipocyte number and it might contribute to reduction of body weight [46-50]. No significant change was seen for liver, kidney and heart weights when compared in experimental groups (Table 2). Some studies showed no significant change in organ weights by BPA administration [39].

In the present study, pubertal spermatogenesis for histomorphometric analysis was characterized by seminiferous tubule diameter, lumen diameter, epithelial and tunica albugenia height. A significant increase was witnessed in interstitial spaces and tubular lumen diameter with exposure to bisphenol analogues. Both BPA low and high dose exposure led to reduce seminiferous tubule diameter, epithelial and tunica albugenia height and germ cells. In our former study by Jahan et al., 2016, it has been reported that administration of BPA in adult rats induces similar changes with low efficiency of spermatogenesis. Studies have shown that not only tissue morphology is affected by BPA but also the number of mature spermatids becomes limited [34]. Similarly, low dose exposed BPS groups underwent a minimal level of damage to epithelial and reduction in lumen diameter, however, seminiferous tubule presented almost same pattern as control and as such no evident damage in high dose BPS exposed group.

In vertebrates and mammals, reproductive system and brain are physiologically and anatomically differentiated in both males and females, as a result of postnatal sex steroids during early development in the hypothalamic sexually differentiated anteroventral periventricular nucleus (AVPV). AVPV region of the brain has multiple cell types that are sexually dimorphic and tyrosine hydroxylase positive cells are one of them [47]. Aromatization of estrogen in the medial region of male brain results in expression of few Tyrosine hydroxylase cell. It is well documented that in rats and mice, neurons of $\mathrm{TH}+$ ve cells in the AVPV of brain act as a potent anatomical marker of brain sexual differentiation [48, 49]. TH neurons number in the AVPV region of brain is effectively reduced by administrating testosterone or estradiol at the perinatal and/or postnatal stage. No sex difference in TH number was seen in ERKO (lack ER) mice, however, mice lacking $\mathrm{TH}$ receptor for androgen maintain sexual dimorphism in $\mathrm{TH}$ number [49]. So through these studies, it might be proposed that ER is important for estrogen action in reducing $\mathrm{TH}$ neuron number in males as compared to females.

The postnatal exposure of bisphenol analogues has displayed no significant effect at low dose $2 \mu \mathrm{g} / \mathrm{kg}$ of BPA and BPS on the total amount of TH-ir neurons in males. Our present results are in line with findings of Patisaul et al. (2006) [24]. But the significant increase 

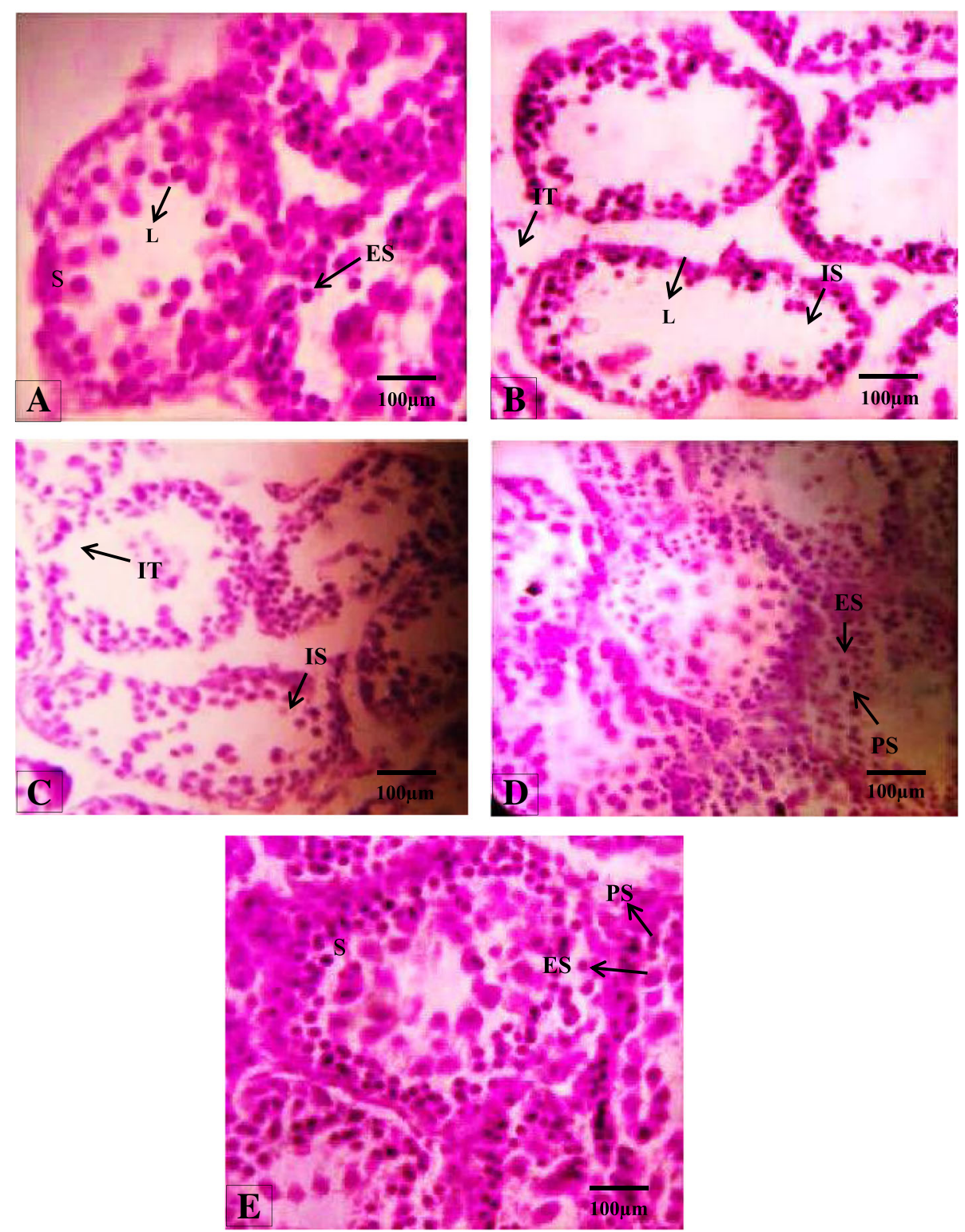

Fig. 1 Photomicroghaph of 27 days old neonatal male rat seminiferous tubules(H\&E, 40X) from: (a) Control; showing normal morphology of closely packed tubules with basal lamina, stratification and increased spermatogenic epithelium Spermatogonia, primary spermatocytes and early spermatids well developed lumen, (b) BPA group treated with $2 \mu \mathrm{g} / \mathrm{kg}$ of dose; showing noticeable increase in interstitial spaces between destructed tubules and basal lamina, decrease in epithelial height, only spermatogonia and large lumen, (c) BPA group treated with $200 \mu \mathrm{mg} / \mathrm{kg}$; showing decreased tubular diameter damaged interstitial tissues and increased interstitial spaces, narrow lumen, (d) BPS $2 \mu \mathrm{m} / \mathrm{kg}$ treated group showing semineferious tubules without interstitial space, minimal damage to epithelial, decrease in lumen diameter, (e) BPS 200 Hg/kg; showing no interstitial space, normal spermatogenesis and basal lamina around tubules and very short lumen with early spermatids. Interstitial space (IS), Spermatogonia(S), Primary spermatocytes (PS), Early spermatids (ES), Epithelial Height (EH), Interstitial tissues (IT), Basal lamina (BL), Lumen (L)

was observed in the number of TH-ir cell bodies with high doses of $200 \mu \mathrm{g} / \mathrm{kg}$ of BPA and BPS. These results indicate that BPA interferes with estrogen action at low dose [28] and acts as antiestrogenic at high doses resulting in demasculinization of positive cells that can lead to reproductive damage in adulthood. The data point that just like BPA, BPS effectively interferes with endogenous estrogen and demasculinizes expression of $\mathrm{TH}$ in AVPV region suggesting that BPA, as well as BPS, play an anti-estrogenic role in the developing brain of male rats. Various scientists also support this idea [24].

The underlying mechanisms behind estrogen actions on $\mathrm{TH}$ expression patterns in AVPV in the neonatal males are not well understood. But it appears to be acting through estrogen receptor signaling. According to 


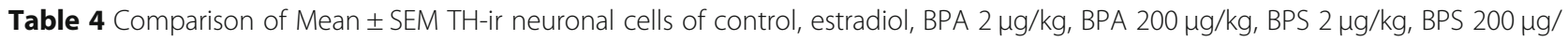
$\mathrm{kg}$ treated groups, in $20 \mu \mathrm{m}$ thick hypothalamic sections of 28 days old male rats

\begin{tabular}{lllllll}
\hline Animals & Control & Estradiol $50 \mu \mathrm{g} / \mathrm{kg}$ & BPA $2 \mu \mathrm{g} / \mathrm{kg}$ & BPA $200 \mu \mathrm{g} / \mathrm{kg}$ & BPS $2 \mu \mathrm{g} / \mathrm{kg}$ & BPS $200 \mu \mathrm{g} / \mathrm{kg}$ \\
\hline 1 & 74.5 & 60.75 & 75 & 163.75 & 183 & 148 \\
2 & 46.25 & 56.25 & 101 & 178.25 & 100.75 & 119.5 \\
3 & 65.25 & 56.5 & 94.75 & 56.5 & 64.5 & 87 \\
TH-ir Cell Bodies & $62 \pm 4.47$ & $57.83 \pm 3.68$ & $90.25 \pm 7.41^{\mathrm{b}^{*}}$ & $175 \pm 8.2^{\text {abc }^{* * *}}$ & $80.08 \pm 10.03^{\mathrm{d}^{* * *}}$ & $118.16 \pm 10.23^{\mathrm{abd} \mathrm{d}^{* * *} \mathrm{e}^{*}}$ \\
\hline
\end{tabular}

Values are expressed as mean SEM

${ }^{*} p<0.05,{ }^{* *} p<0.01, p^{* * *}<0.001$

$\mathrm{a}=$ Values vs control, $\mathrm{b}=$ Values vs Bisphenol A $2 \mu \mathrm{g} / \mathrm{kg}, \mathrm{c}=$ Values vs Bisphenol A $200 \mu \mathrm{g} / \mathrm{kg}, \mathrm{d}=$ Values vs Bisphenol S $2 \mu \mathrm{g} / \mathrm{kg}$

Rubin et al. (2011), a study conducted on the pregnant mice delivering low levels of BPA to their offspring by subcutaneous implanted Alzet pumps resulted into decreased TH cell number in AVPV of females as compared to control male [12]. Simerly et al., (1997) reported that male mice in which $\mathrm{TH}$-ir neurons lack $\mathrm{ERa}$, are phenotypically similar to wild type female mice, suggesting that ERa is important for the normal masculinization of the male brain by estrogen [44-49].

It is also demonstrated that developing AVPV TH-ir cells are sensitive to EACs disruption, reliability of dopaminergic $\mathrm{TH}$ expression patterns make it more vulnerable to examine the sensitivity of EACs in the neonatal brain [50]. Previous epidemiological studies for early life
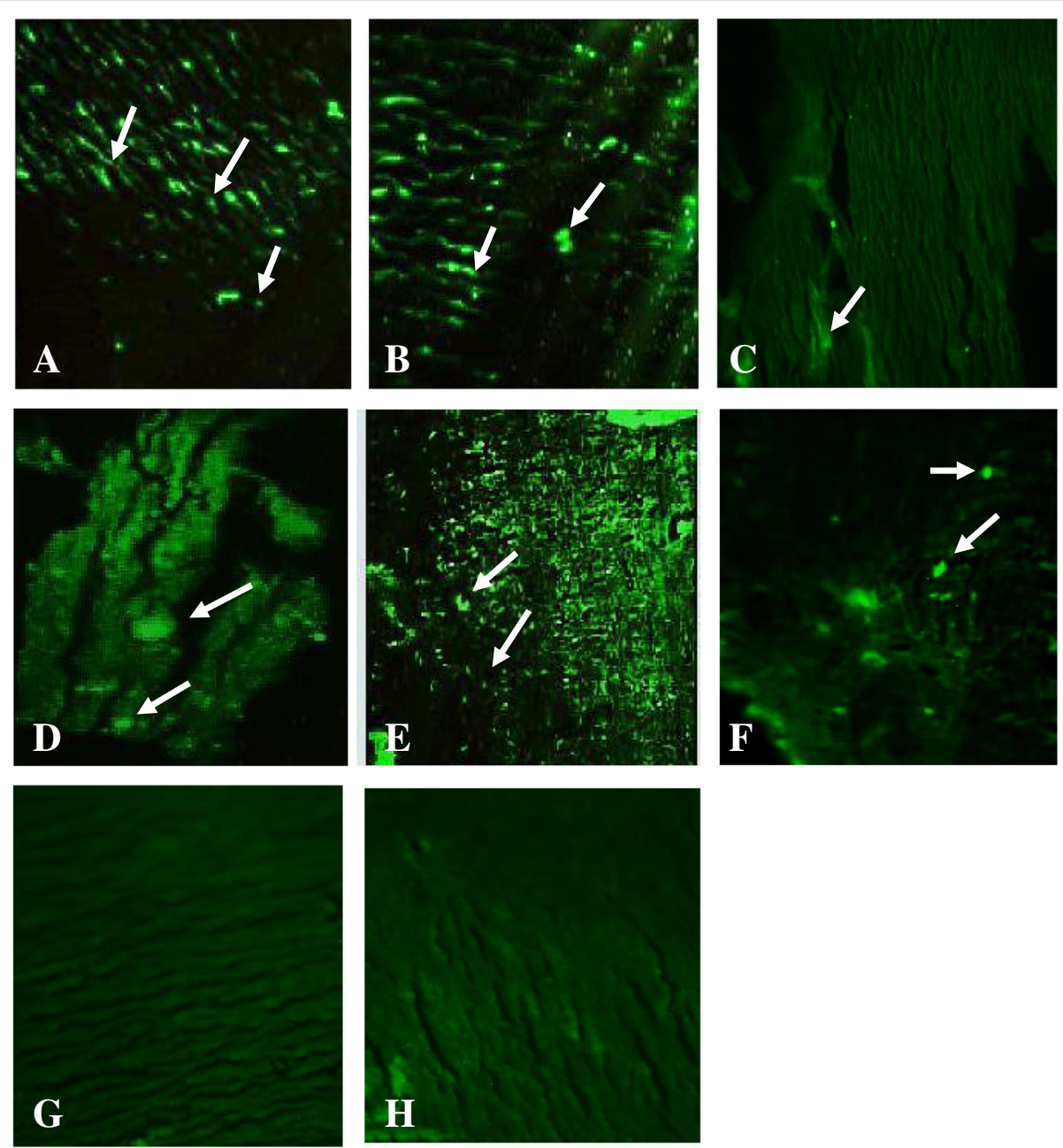

Fig. 2 Photomicrograph (10X) of TH-immunoreactive cells in AVPV of representative Sprague Dawley male rat pups that were neonatal treated with BPA $2 \mu \mathrm{g} / \mathrm{kg}(\mathbf{a})$, BPA $200 \mu \mathrm{g} / \mathrm{kg}(\mathbf{b})$, BPS $2 \mu \mathrm{g} / \mathrm{kg}(\mathbf{c})$, BPS $200 \mu \mathrm{g} / \mathrm{kg}$ (d), Control (e), Estradiol (f). Omitted controls $\mathbf{g}$ and $\mathbf{h}$ show no significance results 
exposure of BPA in young girls in humans associated with a high level of anxiety and hyperactivity suggest that early life BPA exposure has injurious, sex specific and neural effects in humans $[51,52,56]$.

According to observations of the USA population from 2010 to 2014, a trend of using BPS as BPA substitute has led to increased use of this chemical in industrial products [53]. Sexual dimorphism in AVPV volume and $\mathrm{TH}$ neurons are appeared to be influenced by BPA exposure and there are different mechanisms that appear to be responsible to influence both, including cell surviving gene $\mathrm{Bcl}-2$ and $\mathrm{BAX}$ gene deletion and overexpression, they are responsible for cell death reduction in AVPV and eliminated sex differences in AVPV volume in mice [54-57]. However, all these manipulations were failed to alter the $\mathrm{TH}$ neuron number in this nucleus. Beside Bcl-2 family of proteins, other pathways appear to be responsible for a dopaminergic neuron sex difference in AVPV [16].

\section{Conclusion}

The current investigation provides the warning of possible toxic effects of exposure of BPA substitute "BPS" during early life period. Since, BPS exposure during neonatal developmental periods act as endocrine disruptors and could have serious consequences that might alter systematic organization of reproductive organs and brain's sex specific regions leading to severe reproductive health concerns in adulthood. Future studies are required for risk assessment of bisphenols on the sexual differentiation of AVPV region of females and to uncover mechanisms through which these bisphenols affect dimorphism of AVPV region in both sexes. Thus, we proposed that BPS cannot be recommended as a safer alternative of BPA.

\section{Acknowledgements}

We are grateful to the Deanship of Scientific Research at King Saud University for its funding of this research through Research Group Project number 193.

\section{Authors' contributions}

$\mathrm{N}, \mathrm{SJ}$ and HR designed and conceived the study, and analyzed the results. N, $H R$ and MD performed experiment and compiling the results. N, HR, IA, SR, WU and TA wrote the manuscript and did interpretation of data. WU, MD, $\mathrm{SR}, \mathrm{TA}$ and $\mathrm{AA}$ made substantial contribution in revising the manuscript for intellectual content. All authors read and approved the final manuscript.

\section{Funding}

We are grateful to the Deanship of Scientific Research at King Saud University for its funding of this research through Research Group Project number 193.

\section{Availability of data and materials}

The datasets used and/or analyzed during the current study are available from the corresponding author on reasonable request.

\section{Ethics approval and consent to participate}

This study makes use of rats, and the experimental protocol for the use of animal was approved (BAS\#0256) by the ethical board of Quaid-i-Azam University, Islamabad Pakistan.

Consent for publication

Not applicable.

\section{Competing interests}

The authors declare that they have no competing interests.

Received: 14 March 2019 Accepted: 10 June 2019

Published online: 10 July 2019

References

1. Anway MD, Skinner MK. Epigenetic transgenerational actions of endocrine disruptors. Endocrinology. 2006;147:s43-9.

2. Arnich $N$, Canivenc-Lavier M-C, Kolf-Clauw M, Coffigny H, Cravedi J-P, Grob K, Macherey A-C, Masset D, Maximilien R, Narbonne J-F. Conclusions of the French food safety agency on the toxicity of bisphenol A. Int J Hyg Environ Health. 2011:214:271-5.

3. Braun JM, Kalkbrenner AE, Calafat AM, Bernert JT, Ye X, Silva MJ, Barr DB, Sathyanarayana S, Lanphear BP. Variability and predictors of urinary bisphenol a concentrations during pregnancy. Environ Health Perspect. 2011;119:131-40.

4. $\mathrm{Bu} L$, Lephart ED. AVPV neurons containing estrogen receptor-beta in adult male rats are influenced by soy isoflavones. BMC Neurosci. 2007:8:13-20.

5. Calafat AM, Ye X, Wong L-Y, Reidy JA, Needham LL. Exposure of the US population to bisphenol a and 4-tertiary-octylphenol: 2003-2004. Environ Health Perspect. 2008;116:139.

6. Caserta D, Mantovani A, Marci R, Fazi A, Ciardo F, La Rocca C, Maranghi F, Moscarini M. Environment and women's reproductive health. Hum Reprod Update. 2011;17:418-33.

7. Catanese MC, Vandenberg LN. Bisphenol S (BPS) alters maternal behavior and brain in mice exposed during pregnancy/lactation and their daughters. Endocrinology. 2016;158:516-30.

8. Chen Y, Shu L, Qiu Z, Lee DY, Settle SJ, Hee SQ, Telesca D, Yang X, Allard P. Exposure to the BPA-substitute bisphenol $S$ causes unique alterations of germline function. PLoS Genet. 2016;12:e1006223-32.

9. Colledge WH. Kisspeptins and $\mathrm{GnRH}$ neuronal signalling. Trends Endocrinol Metab. 2009:20:115-21.

10. Coulier L, Bradley EL, Bas RC, Verhoeckx KCM, Driffield M, Harmer N, Castle L. Analysis of reaction products of food contaminants and ingredients: bisphenol a diglycidyl ether (BADGE) in canned foods. J Agric Food Chem. 2010;58:4873-82.

11. Eladak S, Grisin T, Moison D, Guerquin M-J, N'Tumba-Byn T, Pozzi-Gaudin S, Benachi A, Livera G, Rouiller-Fabre V, Habert R. A new chapter in the bisphenol a story: bisphenol $\mathrm{S}$ and bisphenol $\mathrm{F}$ are not safe alternatives to this compound. Fertil Steril. 2015;103:11-21.

12. Forger NG, Rosen GJ, Waters EM, Jacob D, Simerly RB, De Vries GJ. Deletion of Bax eliminates sex differences in the mouse forebrain. Proc Natl Acad Sci U S A. 2004;101:13666-71.

13. Gámez JM, Penalba R, Cardoso N, Ponzo O, Carbone S, Pandolfi M, Scacchi $P$, Reynoso R. Low dose of bisphenol a impairs the reproductive axis of prepuberal male rats. J Physiol Biochem. 2014;70:239-46.

14. Gore AC. Neuroendocrine systems as targets for environmental endocrinedisrupting chemicals. Fertil Steril. 2008;89:e101.

15. Gregoraszczuk EL, Ptak A. Endocrine-disrupting chemicals: some actions of POPs on female reproduction. Int J Endocrinol. 2013;2013-20.

16. Henley DV, Korach KS. Endocrine-disrupting chemicals use distinct mechanisms of action to modulate endocrine system function. Endocrinology. 2006:147:s25-32.

17. Hong J, Chen F, Wang X, Bai Y, Zhou R, Li Y, Chen L. Exposure of preimplantation embryos to low-dose bisphenol A impairs testes development and suppresses histone acetylation of StAR promoter to reduce production of testosterone in mice. Mol Cell Endocrinol. 2016;427: 101-11.

18. Jacob DA, Temple JL, Patisaul HB, Young $\sqcup$, Rissman EF. Coumestrol antagonizes neuroendocrine actions of estrogen via the estrogen receptor a. Exp Biol Med. 2001;226:301-6. 
19. Jahnukainen K, Chrysis D, Hou M, Parvinen M, Eksborg S, Söder O. Increased apoptosis occurring during the first wave of spermatogenesis is stagespecific and primarily affects midpachytene spermatocytes in the rat testis. Biol Reprod. 2004;70:290-6.

20. Ji K, Hong S, Kho Y, Choi K. Effects of bisphenol S exposure on endocrine functions and reproduction of zebrafish. Environ Sci Technol. 2013;47:8793-800

21. Jin P, Wang X, Chang F, Bai Y, Li Y, Zhou R, Chen L. Low dose bisphenol a impairs spermatogenesis by suppressing reproductive hormone production and promoting germ cell apoptosis in adult rats. J Biomed Res. 2013;27:135.

22. Kavlock RJ, Daston GP, DeRosa C, Fenner-Crisp P, Gray LE, Kaattari S, Lucier G, Luster M, Mac MJ, Maczka C. Research needs for the risk assessment of health and environmental effects of endocrine disruptors: a report of the US EPA-sponsored workshop. Environ Health Perspect. 1996;104:715.

23. Kazim SF, del Carmen Cardenas-Aguayo M, Arif M, Blanchard J, Fayyaz F, Grundke-lqbal I, lqbal K. Sera from children with autism induce autistic features which can be rescued with a CNTF small peptide mimetic in rats. PLoS One. 2015;10:e0118627.

24. Kinch CD, Ibhazehiebo K, Jeong J-H, Habibi HR, Kurrasch DM. Low-dose exposure to bisphenol $A$ and replacement bisphenol $S$ induces precocious hypothalamic neurogenesis in embryonic zebrafish. Proc Natl Acad Sci. 2015;112:1475-80.

25. Kuruto-Niwa R, Nozawa R, Miyakoshi T, Shiozawa T, Terao Y. Estrogenic activity of alkylphenols, bisphenol $\mathrm{S}$, and their chlorinated derivatives using a GFP expression system. Environ Toxicol Pharmacol. 2005;19:121-30.

26. Liao C, Kannan K. Concentrations and profiles of bisphenol A and other bisphenol analogues in foodstuffs from the United States and their implications for human exposure. J Agric Food Chem. 2013;61:4655-62.

27. Liao C, Liu F, Alomirah H, Loi VD, Mohd MA, Moon H-B, Nakata H, Kannan K. Bisphenol $\mathrm{S}$ in urine from the United States and seven Asian countries: occurrence and human exposures. Environ Sci Technol. 2012;46:6860-6.

28. Liu C, Duan W, Zhang L, Xu S, Li R, Chen C, He M, Lu Y, Wu H, Yu Z. Bisphenol $A$ exposure at an environmentally relevant dose induces meiotic abnormalities in adult male rats. Cell Tissue Res. 2014;355:223-32.

29. Ma S, Shi W, Wang X, Song P, Zhong X. Bisphenol a exposure during pregnancy alters the mortality and levels of reproductive hormones and genes in offspring mice. Biomed Res Int. 2017;2017.

30. McCaffrey KA, Jones B, Mabrey N, Weiss B, Swan SH, Patisaul HB. Sex specific impact of perinatal bisphenol A (BPA) exposure over a range of orally administered doses on rat hypothalamic sexual differentiation. Neurotoxicology. 2013;36:55-62.

31. Molina-Molina J-M, Amaya E, Grimaldi M, Sáenz J-M, Real M, Fernández MF, Balaguer $\mathrm{P}$, Olea $\mathrm{N}$. In vitro study on the agonistic and antagonistic activities of bisphenol-S and other bisphenol-A congeners and derivatives via nuclear receptors. Toxicol Appl Pharmacol. 2013;272:127-36.

32. Naciff JM, Hess KA, Overmann GJ, Torontali SM, Carr GJ, Tiesman JP, Foertsch LM, Richardson BD, Martinez JE, Daston GP. Gene expression changes induced in the testis by transplacental exposure to high and low doses of 17a-ethynyl estradiol, genistein, or bisphenol A. Toxicol Sci. 2005; 86:396-416.

33. Naderi M, Wong MYL, Gholami F. Developmental exposure of zebrafish (Danio rerio) to bisphenol-S impairs subsequent reproduction potential and hormonal balance in adults. Aquat Toxicol. 2014;148:195-203.

34. Ogonuki N, Inoue K, Hirose M, Miura I, Mochida K, Sato T, Mise N, Mekada K, Yoshiki A, Abe K. A high-speed congenic strategy using first-wave male germ cells. PLoS One. 2009;4:e4943.

35. Orikasa C, Sakuma Y. Possible involvement of preoptic estrogen receptor $\beta$ positive cells in luteinizing hormone surge in the rat. Domest Anim Endocrinol. 2003;25:83-92

36. Patisaul HB, Fortino AE, Polston EK. Neonatal genistein or bisphenol-A exposure alters sexual differentiation of the AVPV. Neurotoxicol Teratol. 2006;28:111-8

37. Phrakonkham $P$, Viengchareun $S$, Belloir $C$, Lombès $M$, Artur $Y$, CanivencLavier M-C. Dietary xenoestrogens differentially impair 3T3-L1 preadipocyte differentiation and persistently affect leptin synthesis. J Steroid Biochem Mol Biol. 2008;110:95-103.

38. Rajasärkkä J, Koponen J, Airaksinen R, Kiviranta H, Virta M. Monitoring bisphenol A and estrogenic chemicals in thermal paper with yeast-based bioreporter assay. Anal Bioanal Chem. 2014;406:5695-702.

39. Ramsay DJ, Booth D. Thirst: physiological and psychological aspects: Springer Science \& Business Media; 2012.
40. Richter CA, Birnbaum LS, Farabollini F, Newbold RR, Rubin BS, Talsness CE, Vandenbergh JG, Walser-Kuntz DR, vom Saal FS. In vivo effects of bisphenol A in laboratory rodent studies. Reprod Toxicol. 2007;24:199-224.

41. Rubin BS. Bisphenol A: an endocrine disruptor with widespread exposure and multiple effects. J Steroid Biochem Mol Biol. 2011;127:27-34.

42. Rubin BS, Lenkowski JR, Schaeberle CM, Vandenberg LN, Ronsheim PM, Soto AM. Evidence of altered brain sexual differentiation in mice exposed perinatally to low, environmentally relevant levels of bisphenol A. Endocrinology. 2006;147:3681-91.

43. Rubin BS, Murray MK, Damassa DA, King JC, Soto AM. Perinatal exposure to low doses of bisphenol A affects body weight, patterns of estrous cyclicity, and plasma LH levels. Environ Health Perspect. 2001;109:675.

44. Sakaue M, Ohsako S, Ishimura R, Kurosawa S, Kurohmaru M, Hayashi Y, Aoki Y, Yonemoto J, Tohyama C. Bisphenol-A affects spermatogenesis in the adult rat even at a low dose. J Occup Health. 2001;43:185-90.

45. Salian S, Doshi T, Vanage G. Neonatal exposure of male rats to bisphenol A impairs fertility and expression of sertoli cell junctional proteins in the testis. Toxicology. 2009;265:56-67.

46. Schlesser HN. Effect of endocrine disruptors on the male mouse reproductive system: University of Illinois at Urbana-Champaign; 2009.

47. Semaan SJ, Kauffman AS. Sexual differentiation and development of forebrain reproductive circuits. Curr Opin Neurobiol. 2010;20:424-31.

48. Simerly RB, Swanson LW, Gorski RA. The distribution of monoaminergic cells and fibers in a periventricular preoptic nucleus involved in the control of gonadotropin release: immunohistochemical evidence for a dopaminergic sexual dimorphism. Brain Res. 1985;330:55-64.

49. Simerly RB, Zee MC, Pendleton JW, Lubahn DB, Korach KS. Estrogen receptor-dependent sexual differentiation of dopaminergic neurons in the preoptic region of the mouse. Proc Natl Acad Sci. 1997;94:14077-82.

50. Song S, Zhang L, Zhang H, Wei W, Jia L. Perinatal BPA exposure induces hyperglycemia, oxidative stress and decreased adiponectin production in later life of male rat offspring. Int J Environ Res Public Health. 2014;11:3728-42.

51. Soto AM, Brisken C, Schaeberle C, Sonnenschein C. Does cancer start in the womb? Altered mammary gland development and predisposition to breast cancer due to in utero exposure to endocrine disruptors. J Mammary Gland Biol Neoplasia. 2013;18:199-208.

52. Takemura H, Ma J, Sayama K, Terao Y, Zhu BT, Shimoi K. In vitro and in vivo estrogenic activity of chlorinated derivatives of bisphenol A. Toxicology. 2005;207:215-21.

53. Uenoyama $Y$, Pheng $V$, Tsukamura $H$, Maeda $K$. The roles of kisspeptin revisited: inside and outside the hypothalamus. J Reprod Dev. 2016;62:537-45.

54. Ullah H, Jahan S, Ain QU, Shaheen G, Ahsan N. Effect of bisphenol S exposure on male reproductive system of rats: a histological and biochemical study. Chemosphere. 2016;152:383-91.

55. Wolstenholme JT, Rissman EF, Connelly JJ. The role of bisphenol A in shaping the brain, epigenome and behavior. Horm Behav. 2011;59:296-305.

56. Ye $X$, Wong L-Y, Kramer J, Zhou X, Jia T, Calafat AM. Urinary concentrations of bisphenol $\mathrm{A}$ and three other bisphenols in convenience samples of US adults during 2000-2014. Environ Sci Technol. 2015;49:11834-39.

57. Zup SL, Carrier H, Waters EM, Tabor A, Bengston L, Rosen GJ, Simerly RB, Forger NG. Overexpression of bcl-2 reduces sex differences in neuron number in the brain and spinal cord. J Neurosci. 2003;23:2357-62.

\section{Publisher's Note}

Springer Nature remains neutral with regard to jurisdictional claims in published maps and institutional affiliations.

Ready to submit your research? Choose BMC and benefit from:

- fast, convenient online submission

- thorough peer review by experienced researchers in your field

- rapid publication on acceptance

- support for research data, including large and complex data types

- gold Open Access which fosters wider collaboration and increased citations

- maximum visibility for your research: over $100 \mathrm{M}$ website views per year

At $\mathrm{BMC}$, research is always in progress.

Learn more biomedcentral.com/submission 